\title{
Влияние русских традиций на формирование усадебно-жилищного комплекса хакасов в Хакасско-Минусинском крае в XIX-XX вв.
}

\author{
Валентина Н. Тугужекова, Евгений В. Прищепа
}

Хакасский научно-исследовательский институт языка, литературы и истории, Российская Федерация
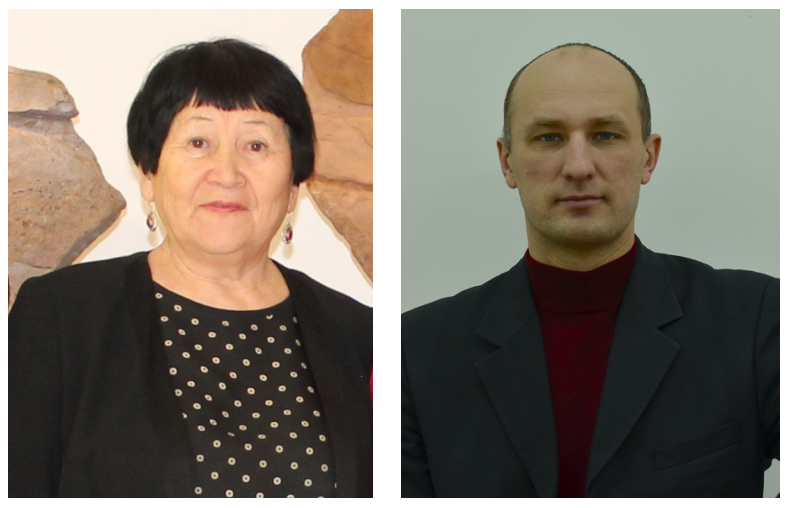

Статья посвящена проблемам развития усадебножилищного комплекса коренных жителей ХакасскоМинусинского края в ХІХ-XX вв. Культурно-экономические связи хакасов с русскими в результате освоения и заселения края привели к соприкосновению разных культурных традиций, что послужило началу проиеессов культурного взаимодействия. Важное место в этом взаимодействии занимает развитие и эволюция основных типов их усадебно-жилищных комплексов.

Процессы развития единого жилищно-усадебного комплекса хакасов начинались с трансформаций традиционных поселений, появления смешанных форм усадебно-жилищных комплексов с активной нивелировкой этнически значимых черт и сохранением лишь отдельных традиционных элементов. Постепенно распространение хозяйственных построек русского образца становится в крае повсеместным.

В результате уже в начале XX в. происходит складывание локальной хакасской усадьбы, в которой в пределах зимника и летника располагаются заимствованные у русских хозяйственные постройки и жилища, а коренные жители находятся на постоянном местожительстве. Для второй половины ХХ в. характерно уже складывание усадебно-жилищного комплекса хакасов на манер русской строительной традиции: с уличной застройкой, комплексом хозяйственных и жилищных построек земледельческо-скотоводческой направленности.

Ключевые слова: Хакасско-Минусинский край; Хакасия; жилищно-усадебный комплекс; хакасы; русские; традищионное жилище

\section{Для цитирования:}

Тугужекова В. Н., Прищепа Е. В. Влияние русских традиций на формирование усадебно-жилищного комплекса хакасов в Хакасско-Минусинском крае в XIX-XX вв. [Электронный ресурс] // Новые исследования Тувы. 2019, № 1. URL: https://nit.tuva.asia/nit/article/view/836 (дата обращения: дд.мм. гг.). DOI: 10.25178/nit.2019.1.12

Тугужекова Валентина Николаевна - доктор исторических наук, директор Хакасского научно-исследовательского института языка, литературы и истории. Адрес: 655017, Россия, г. Абакан, ул. Щетинкина, д. 23. Тел.: +7 (3902) 22-37-58. Эл. адрес: khaknauka@yandex.ru

Прищепа Евгений Валерьевич - кандидат исторических наук, старший научный сотрудник сектора экономики и социологии Хакасского научно-исследовательского института языка, литературы и истории. Адрес: 655017, Россия, г. Абакан, ул. Щетинкина, д. 23. Тел.: +7 (3902) 22-37-58. Эл. адрес: prievg@mail.ru ORCID:0000-0002-0344-3179

Tuguzhekova Valentina Nikolayevna, Doctor of History, Director, Khakass Research Institute of Language, Literature and History. Postal address: 23 Shchetinkin St., Abakan, 655017 Russia. Tel.:+7 (3902) 22-37-58. E-mail:khaknauka@ yandex.ru

Prishchepa Evgeniy Valeryevich, Candidate of History, Senior research fellow, Department of economics and sociology, Khakass Research Institute of Language, Literature and History. Postal address: 23 Shchetinkin St., Abakan, 655017 Russia. Tel.: +7 (3902) 22-37-58. E-mail: pri-evg@mail.ru 


\title{
The influence of Russian traditions on the formation of Khakass farm housing in Khakass-Minusinsk region in 19th - 20th centuries"
}

\author{
Valentine N. Tuguzhekova, Evgeny V. Prischepa \\ Khakass Research Institute of Language, Literature and History, Russian Federation
}

\begin{abstract}
The article deals with the problems of the development of farm housing among the indigenous inhabitants of Khakass-Minusinsk region in the 19th and 20th centuries. As a result of the development and settlement of the region, the cultural and economic relationships of the Khakass people with the Russians meant establishing contacts between different cultural traditions. This triggered the process of cultural interaction, an important place wherein belonged to the development and evolution of the main types of farm housing.

It began with the transformation of traditional settlements and with the appearance of the mixed forms of farm housing where ethnically significant features underwent radical erosion, preserving only some of the traditional elements. Progressively, the Russian-type farm buildings became widespread throughout the region. As a result, the early 20th century witnessed a formation of Khakass farmhouse, which featured both winter and summer outbuildings and houses (a practice borrowed from Russians), thus enabling indigenous farmers to live on the farm permanently. In the second half of the 20th century, the design of the Khakass farm housing modeled on the Russian tradition becomes typical, with its street orientation, and the complex of living quarters and outbuildings of agricultural and cattle-breeding use.
\end{abstract}

Keywords: Khakass-Minusinsk region; Khakassia; farm housing; Khakass; Russians; traditional housing

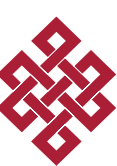

\section{For citation:}

Tuguzhekova V. N., Prischepa E. V. The influence of Russian traditions on the formation of Khakass farm housing in Khakass-Minusinsk region in 19th - 20th centuries. The New Research of Tuva, 2019, no. 1 [online] Available at: https://nit.tuva.asia/nit/article/view/836 (accessed: ...). DOI: 10.25178/nit.2019.1.12

\section{Введение}

Актуальность темы исследования обусловлена произошедшими изменениями в культурно-бытовой жизни коренного населения края в рассматриваемый период, что представляет особый интерес, так как жилищно-усадебный комплекс выполняет функцию этнических определителей.

Развитие усадебно-жилищного комплекса построек у титульного этноса Хакасско-Минусинского края (далее - ХМК) происходило в результате складывания культурных контактов с пришлым русским населением региона. Большое влияние на развитие оказал переход коренных жителей на оседлый образ жизни и заимствование культуры земледелия. Характерно, что развитие жилища в новых его формах шло синхронно вхождению в быт хозяйственных построек и имело комплементарный характер. Сложно сказать, что являлось определяющим - развитие жилища или усадебного комплекса построек, но отмечено, что тенденции развития нарастают по мере расширения совместного проживания хакасов и русских друг с другом, что в конечном итоге приводит к формированию нового типа усадьбы. Таким образом, изменение образа жизни неизбежно влекло и изменение форм материальной культуры, что существенно сказалось на формировании и развитии усадебно-жилищного комплекса хакасов в период XIX-XX вв.

В работе представлен анализ особенностей развития усадебно-жилищного комплекса построек хакасов - коренного населения Хакасии, уточнению периода исчезновения и возникно- 
вения ряда хозяйственных построек у коренного населения региона, степени заимствования и сохранения традиционных построек хакасов в период XIX-XX вв. Задачи: изучение изменений, произошедших вследствие взаимокультурных контактов и исторического развития жилищноусадебного комплекса построек; изучение специфики развития усадебного комплекса в связи с изменением вида хозяйственной деятельности и переходу хакасов на оседлость.

В работе авторы опираются на единство сравнительно-исторического, историко-типологического и историко-генетического подходов, что позволяет нам рассматривать многообразие методологических концепций многоаспектно, по принципу взаимодополняемости с точки зрения раскрытия в них закономерностей исторической эволюции и функциональных элементов материальной культуры населения ХМК.

Архивные материалы, использованные в работе, представлены документами архивов Русского географического общества (АРГО, Сведения этнографические о Шушенской волости Минусинского уезда Енисейской губернии (без начала, без даты), p. 57, оп.1, № 2, 60 л.), Минусинского филиала Государственного архива Красноярского края (МФ ГАКК, Помощник производителя работ по отводу земельных участков. Ф. 71, оп. 3, д. 62, л. 93-96, 125-129). Источниковая база исследования также основывается на полевых материалах авторов, собранных в Хакасско-Минусинском крае, на протяжении 1995-2018 гг. Все данные от информантов хранятся в личных архивах авторов. Использованы также неопубликованные результаты исследований этнографа Ю. А. Шибаевой, хранящиеся в Рукописном Фонде ХакНИИЯЛИ (г. Абакан): Хакасское жилище. ХакНИИЯЛИ, Рук. Фонд № 352.140 с.; Чертежи по жилищу хакасов (55 чертежей), ХакНИИЯЛИ, Рук. Фонд № 352 (приложение). Ее работы представляют большой интерес с этнографической точки зрения, поскольку описывают усадебно-жилищный комплекс хакасского населения региона, на рубеже еще существования традиционных жилищ и массового перехода к жилищам русского типа. Данные позволяют выявлять особенности процесса их исторического развития, в сравнении с предшествующим периодом времени.

Все перечисленные источники, при разной степени информативности, обеспечивают исследование сложных процессов генезиса усадебно-жилищного комплекса хакасов в XIX-XX вв. в процессе взаимокультурного взаимодействия народов ХМК.

\section{Степень изученности темы}

Уровень и степень развития этнографической науки, методологические подходы, исторические особенности определенных эпох определяют степень изученности и создают специфику темы.

Дореволюционный период в основном представлен сведениями служилых людей, путешественников, исследователей, государственных чиновников, побывавших в крае и оставивших свидетельства о материальной культуре населения. К таковым при всей их многочисленности, наиболее информативным для нас, можно отнести описания быта этого населения, составленные П. С. Палласом (Паллас, 1788), И. Г. Георги (Георги, 1799). Данные работы носили в основном описательный характер и до сих пор представляют значительный интерес для этнографической науки. Особое место занимают исследования первого ученого Хакасии Н. Ф. Катанова, описывающие образ жизни и быта тюркоязычных групп Минусинской котловины и предгорий Западных Саян. К сожалению, большая часть материалов первой экспедиции Н. Ф. Катанова не опубликована (Тугужекова, 2018: 259). Дореволюционный период в целом знаменовался процессами накопления фактологического материала по жилищно-бытовой культуре населения края при слабом методологическом уровне развитии исторической науки.

Середина XIX в. знаменуется временем научного изучения народной культуры, является началом накопления конкретных этнографических материалов и развитием сибирского краеведения. Содержательной работой рубежа XIX-XX вв. является этнографическое исследование А. А. Кузнецовой (Кузнецова, 1898). Исследование содержит описания традиционных 
усадеб хакасов в конце XIX - начале XX в. и началу вхождения в их быт жилищ русского типа. В целом в работе рассматриваются вопросы их типологии и технологии строительства, распространенные в крае.

Советский период знаменовался процессами становления и развития советской науки. K значимым этнографическим и историческим работам, посвященным, в том числе отчасти генезису усадебного комплекса хакасов, следует отнести, прежде всего, исследования К. М. Патачакова (Патачаков, 1956, 1982).

Исследования Ю. А. Шибаевой, хранящиеся в рукописном фонде ХакНИИЯЛИ, воссоздают особенности усадебного комплекса коренного населения середины XX в. (Шибаева, Хакасское жилище; Чертежи по жилищу хакасов; Отчёт об этнографическом обследовании кызыльцев Ширинского и Саралинского районов в июле 1951 г.). Современный период развития исторической науки знаменовался появлением работ, в которых уделено место теме усадьбы хакасов. Такими работами, написанными на основе полевых, архивных и литературных материалов, являются исследования В. Я. Бутанаева (Бутанаев, 1998, 2002). В его работах описаны их конструкции, в том числе в процессе исторического перехода от кочевого к оседлому образу жизни.

Данное исследование продолжает работу авторов по проблемам генезиса усадебно-жилищного комплекса у народов ХМК, в частности проблемам жилищной сферы, посвящена работа Е. В. Прищепы, одного из соавторов, у которого в 2018 г. вышла монография (Прищепа, 2018). В работе прослеживается комплементарный характер этнокультурных взаимодействий в области материальных культур народов XMК в XVIII-XX вв. В исследовании автор выражает мысль, что строительная культура коренного населения в большей степени оказалась подвержена трансформации и изменениям под влиянием культуры пришлого населения края.

Исторически, в зависимости от природно-географических особенностей Хакасско-Минусинского края, традиционными хозяйственными занятиями хакасов являлись: скотоводство полукочевого типа, охота, земледелие (залежная система полеводства) (Очерки истории Хакасии, 2008: 305, 317, 323). Комплексный характер хозяйства хакасов, определялся естественными разнообразными природно-климатическими условиями существования края - это и степные районы, подтаежные и таёжные; резко-континентальный климат территории: резкие температурные перепады, сухие степи и глубокие снега в тайге. Проблеме степени распространения хозяйственных занятий хакасов посвящен ряд работ: А. А. Ярилов (Ярилов, $1906)^{1}$, Л. П. Потапов (Потапов, 1957), Карцов (Карцов, 1959), В. Я. Бутанаев (Бутанаев, 2012).

Определению хозяйственно-культурного типа населения края и его предков в поздней Древности, в Средние века на территории Южной Сибири посвящена работа С. Г. Скобелева (Скобелев, 2017). В ней автор ставит задачу преодоления распространенного сложившегося стереотипа о енисейских кыргызах и их предках как о преимущественно кочевом народе. По признаку основного хозяйственного занятия, по мнению С. Г. Скобелева, предки кыргызов гянгуни были скотоводы, население Кыргызской земли до XIII в. - земледельцы (при условии существования комплексного хозяйства), с XIII в. (уверенно с XIV в. и до второй половины XIX в.), после чего (во второй половине XIX в.) они вновь стали земледельцы (там же: 83). Тем самым исторически изменение условий хозяйственных и культурно-бытовых форм жизни влекло и изменение форм материальной культуры у родоплеменных групп хакасов: сагайцев, качинцев, кызыльцев и бельтыр. Данные изменения, например, нашли свое отражение в типологии жилищ: в XIX-XX вв. получают распространение как переносные их виды (тос иб, киис иб), так и постоянные жилища срубного типа (тура, адаг иб).

Новые условия жизни привели к тому, что в конце XIX в. земледелие у хакасов получает новый толчок к развитию и становится одним из основных видов хозяйственной деятель-

\footnotetext{
${ }^{1}$ Ярилов А. А. Гражданская полноправность Минусинских инородцев. Издание «Союза Сибирских инородцев», Минусинск: Типография В. В. Федорова, 1906 // ХакНИИЯлИ Фонд 498 (1). Разные материалы из архива А. А. Ярилова.
} 
ности, определяющим весь последующий период развития, что приводит к корректировкам главных составляющих элементов их культуры жизнеобеспечения.

Колыбель жизни автохтонов способствовала их «культурной эластичности», причем она была выше, по ряду причин, чем у русских-переселенцев. Эту особенность отмечал А. А. Ярилов, говоря о том, что они приспособились к природно-географическим условиям края и в зависимости от мест, являлись и скотоводами, и земледельцами, и охотниками (Ярилов, 1906). Комплексный характер хозяйства коренных жителей способствовал выдвижению на первый план в конце XIX в. земледелия, хотя животноводство давало больше средств к существованию, однако перевод хакасов из кочевых в оседлые (Постановлением Енисейского губернского управления от 28 октября 1911 г.) и приравнивание к русским крестьянам по землепользованию (наделение землей в 15 десятин) ограничило их в необходимых нормах (в 10 раз меньше нормы, необходимой кочевнику) площади выпасов для скота (Мамышева, 2008: 51; 2018: 232).

К концу XIX в. основная масса хозяйств более $80 \%$ перешла на оседлый быт. Чистыми скотоводами оставались качинцы, державшие у себя 60\% скота (Бутанаев, 2002: 14).

В интересующем нас своеобразии усадебно-жилищного комплекса хакасов отражена природно-географическая среда обитания автохтонного этноса, уровень его экономического развития, общественная структура, окружение и другие исторические условия.

В целом анализ состояния историографии проблемы показал, что тема отчасти стала предметом исследований, однако, поставленная в данной работе проблема изучения эволюции усадебно-жилищного комплекса хакасов на основе культурных контактов с русским населением, еще не была предметом комплексного анализа.

\section{История развития усадебно-жилищного комплекса хакасов}

Переход от кочевого быта к оседлому и занятие земледелием становится одним из определяющих факторов в развитии культуры хакасов в XIX-XX вв. Оседлый образ жизни создавал условия для развития жилищного и как следствие усадебного комплекса по русскому образцу, преимущественно для зимних поселений. Развитие усадебного комплекса шло по линии заимствования основных его составляющих у русских, с элементами сохранения и национальной хакасской специфики

Усадьбы-зимники (зимний улус) располагались, как правило, у реки около главных покосов (Клеменц, 2015: 214). Усадьбы-летники, наоборот, были расположены там, где покосов не было. Это место было низкое и прохладное, где нет комаров и в изобилии растет степной ирис (для укрытия скота от солнца). Получает распространение тип комбинированного двора, где жили, не кочуя круглый год, а жилищами служила как изба, так и юрта, либо изба крытая и некрытая, либо изба и юрта, соединяемые в одну постройку избу с сенями - служившим и летним и зимним жилищем (Кузнецова, 1898: 145, 150, 151).

Аалы-зимники в период рубежа XIX-XX вв. уже составляли определенную уличную планировку $^{1}$, что позволяет их характеризовать как долговременные, а постройка домов русского типа к началу XX в. становится преобладающей. Так в 1909-1910 гг. у хакасов насчитывается 6018 деревянных юрт и 6574 дома² $^{2}$

Летники средне-зажиточных хакасов из построек имели юрты для нескольких семей, корьевые шалаши (у богатых для работников), поварни, небольшие амбары, сараи, навесы и некрытые дворы для скота, отдельно лежали дрова. Летние и зимние таборы и заимки имели

\footnotetext{
${ }^{1}$ По подсчетам В. Я. Бутанаева, в 40-е гг. XIX в. 20\% аалов Аскизского ведомства жили оседло. В 80-х гг. не кочевало 55,5\% аалов. В 1909-1910 гг. в Аскизской управе 80\% аалов являлись оседлыми. В к. XIX в. более $80 \%$ хозяйств в хакасских ведомствах перешли на оседлость (Бутанаев, 1981: 80-81).

${ }^{2}$ МФ ГАКК. Помощник производителя работ по отводу земельных участков. Ф. 71, оп. 3, д. 62, лл. 93-96, $125-129$.
} 
также некрытые избушки, состоящие из одной комнаты с очагом, юрты, корьевые шалаши, навесы и некрытые дворы для скота (Кузнецова, 1898: 150-151). Особенностью летника было то, что он вмещал небольшое количество построек, так как необходимость в них отпадала по причине того, что скот пасся в степи. Не было нужды в крытых дворах и разнообразных помещениях как в зимнике. Интересно, что трансформация и отживание традиционного образа жизни с перекочевками с зимника на летник, стремительно происходит именно на рубеже XIX-XX вв., как это было отмечено на примере этнографических данных из поездок Н. Ф. Катанова в Минусинский уезд и округ Енисейской губернии в 1896 и 1900 гг.: «Минусинские татары около полугода (с сентября до конца года или половины апреля) живут в зимниках, где стоят их бревенчатые избы и прочные дворы для скота, а полгода (с марта или половины апреля до сентября) - на летниках, где кроме бревенчатых, берестяных или войлочных юрт да дворов из жердей или плетня, ничего нет» (Катанов, 1897: 5). Если в 1896 г. летники, состоящие из юрт, «да дворов из жердей или плетня», были им отмечены, то уже в 1899 г. о переходе коренного населения на летник уже не упоминалось.

В этот период структура зимника хакасов в большей степени соответствовала традиционному набору хозяйственных и жилых построек русских крестьян края. Летник же, вмещал традиционные жилища и дворы, представляющие собой загородки из жердей и плетня, кроме этого ничего не было. Такое планирование усадьбы и расположение хозяйственных и жилых построек было характерно для традиционного образа жизни хакасов и ряда других народов Сибири, особенно в период, когда их численность была небольшой, а свободной земли вдоволь.

На рубеже XIX-XX вв. происходит образование постоянных жилищ и их группирование (пусть и порой немногочисленных 10-15 жилищ) в аалы, часть из которых уже подобно крестьянским русским деревням имели уличную планировку. Жилища эти, по наблюдениям известного этнографа и знатока обычного права минусинских татар Д. Е. Лаппо, были уже «соединены с землёй и представляли собой недвижимость, как сами инородцы имеют в своих улусах постоянное местожительство, т. е. оседлость» (Лаппо, 2009: 145). Оседлость предполагала их закрепление за определенным улусом, а «перекочевки из зимника в летник и обратно не изменяют местожительства инородца как потому, что летник считается принадлежностью зимника, так и потому, что перекочевки совершаются самое большое верст за 10, а это при условиях степной жизни не имеет значения» (там же). Более того закрепление аборигена за определенным улусом соответствовало духу времени и имело для него особый правовой статус. Без указания улуса, например, в котором состоит на жительстве кочевник ${ }^{1}$, ни инородческая управа, ни родовой староста не в состоянии исполнить по отношению к нему требование должностных лиц (Лаппо, 2009: 146).

Изменения в правовом статусе коренных жителей ХМК были связаны со столыпинской аграрной реформой (Постановление Енисейского губернского управления от 28 октября 1911 г.), что вылилось в постоянстве его закрепления за определенным улусом, вне зависимости от места его пребывания: зимник это или летник, что облегчало, в свою очередь, выполнение им возложенных на него обязанностей.

Зимник (хыстаг) зажиточных хакасов вмещал в себя большее количество жилых и крытых хозяйственных построек, расположенных на большой территории. Из жилых построек на территории усадьбы находились: 8-10 угольных срубных юрт, изба (пятистенок с крыльцом). Амбары и амбарчики, сараи стояли отдельно, но располагались в близости на территории двора с жилыми постройками. Тем самым они образовывали единый двор. К избе прилегал ночной теплый телятник, а сразу за избой располагался конный двор и сеновал (второй сеновал), которые граничили с двором для дойных коров, двором для быков, двором для мелкого скота, теплым хлевом для скота, дневным загоном для овец и хлевом. Все эти постройки

\footnotetext{
${ }^{1}$ Видимо, номинация свидетельствует о стереотипе восприятия русскими коренного жителя Минусинского
} округа. 
огибали территорию двора буквой Г. Отдельно от двора находилась поленница (фото 1). Отдельно было отведено место для огорода, в этом случае размеры такого жилищно-усадебного комплекса составляли 91×50 аршин (65 м × 35,5 м) (Кузнецова, 1898: 148-149).

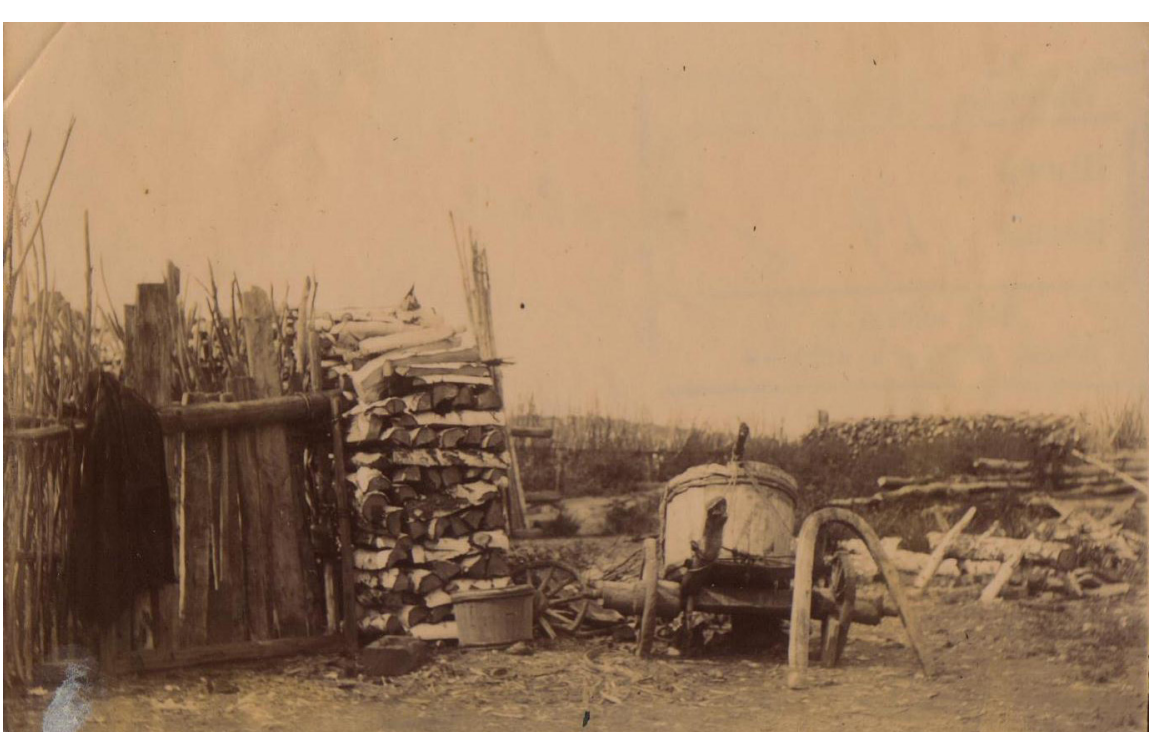

Фото 1. Заготовка дров для бая. Начало ХХ в. (Архив А. А. Ярилова // Рукописный фонд ХакНИИЯЛИ. Ф. 703. Фотокарточки).

Photo 1. Cutting firewood for a rich Khakas. Early 20th century. (The library of A. A. Yarilov // Manuscript fund of KRILLH, F. 703. photographs).

В первой половине XIX в. байские хозяйства меняли места кочевья четыре раза в год, а бедные - не более двух. Впоследствии общинное отношение к земле, что выражалось в пословице Чирнін хулы чоғыл - «Земля не имеет своего раба», т. е. собственность на кочевые просторы отсутствуют, трансформируется.

Если прежде каждый аал (полукочевое селение) имел свое закрепленное место для зимника и летника, а летние пастбища являлись общими владениями и представляли собой объединение несколь-

ких аалов, то к концу XIX в. ситуация меняется. Территории общего пользования: летние пастбища ${ }^{1}$ обретают своих постоянных хозяев, что свидетельствует об угасании яйлажного ${ }^{2}$ (отгонного) скотоводства и переходу от полукочевого хозяйства к оседлости. Усадебные постройки (улёк) считались собственностью хозяина, но это место не было наследственным и на нем мог поселиться кто-либо другой (Бутанаев, 2002: 18, 56, 58, 64, 88).

В конце XIX в. в хакасских улусах, население которых занималось хлебопашеством, кроме жилых построек встречаются юрты-поварни (айран ибы), амбары для хлеба и небольшие амбары (амбарушки), предназначенные для хозяйственного инвентаря. Встречались также сараи (хаза) и навесы. Более обрусевшие имели погреба и ледники, бани (мылча), овины, риги и водяные мельницы (мутовки) $)^{3}$ (фото 2).

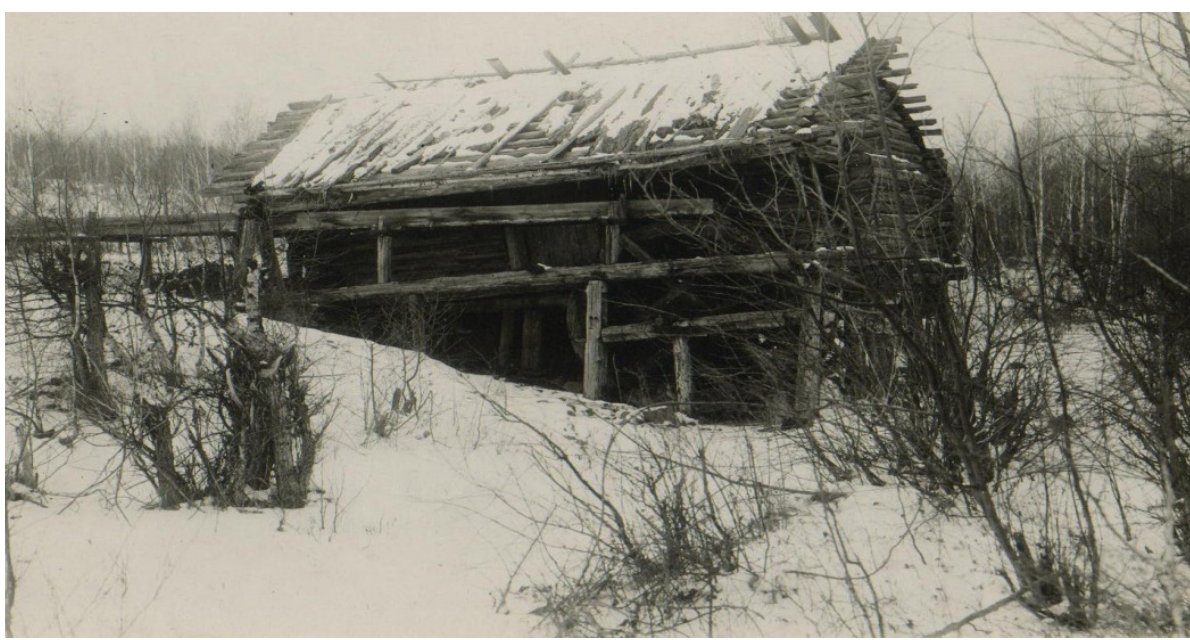

Фото 2. Мельница. Двор зимой. Начало ХХ в. (Архив А. А. Ярилова // Рук. фонд ХакНИИЯЛИ. Ф. 703. Фотокарточки).

Photo 2. A mill at a backyard in winter. Early 20th century (The library of A. A. Yarilov // Manuscript fund of KRILLH, F. 703. photographs).

\footnotetext{
${ }^{1}$ Также и охотничьи угодья.

${ }^{2}$ Полукочевой тип скотоводства, предполагающий постоянные зимние и летние кочевки.

${ }^{3}$ Особенно были распространены в Кизильской и Мелецких управах (Кузнецова, 1898: 142).
} 
Некоторые улусы имели общие колодцы и общественные печи для выпечки хлеба (кирпичные или битые из глины). Этими печами пользовались несколько хозяйств или же весь улус (фото 3) (Кузнецова, 1898: 142).

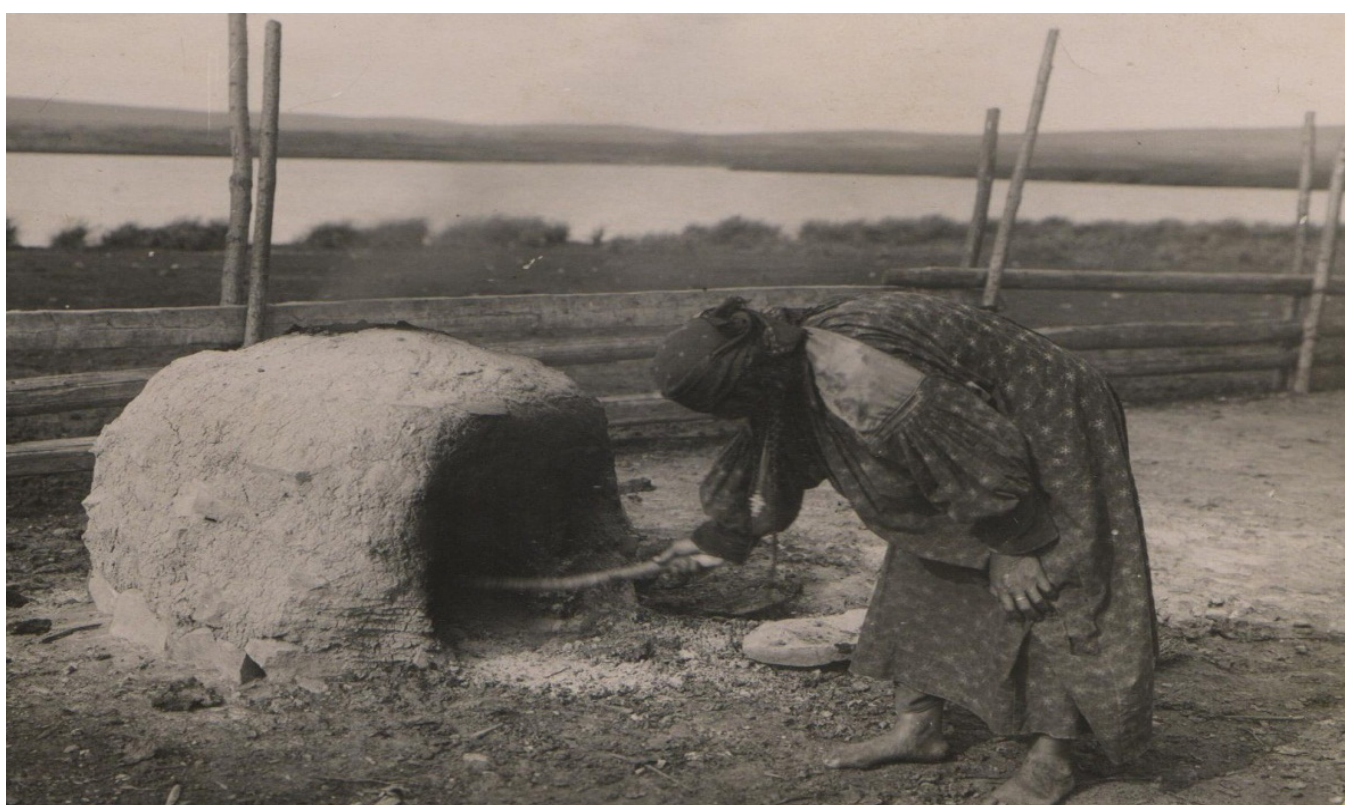

Фото 3. Общественная печь. Улус Райково. Фото Н. В. Федорова, 1912 г. (К. М. Патачаков Быт и культура хакасов в иллюстрациях (ХІХ - начало ХХ в.). Абакан, 1994. // Рук. Фонд ХакНИИЯЛИ, Д. 924.$)$

Photo 3. A community oven. Ulus Raikovo. Photo by N. V. Fedorov, 1912. (from K. M. Patachakov's Everyday life and culture of Khakass people in illustrations (19th - early 20th centuries). Abakan, 1994. // Manuscript fund of KRILLH, D. 924.)

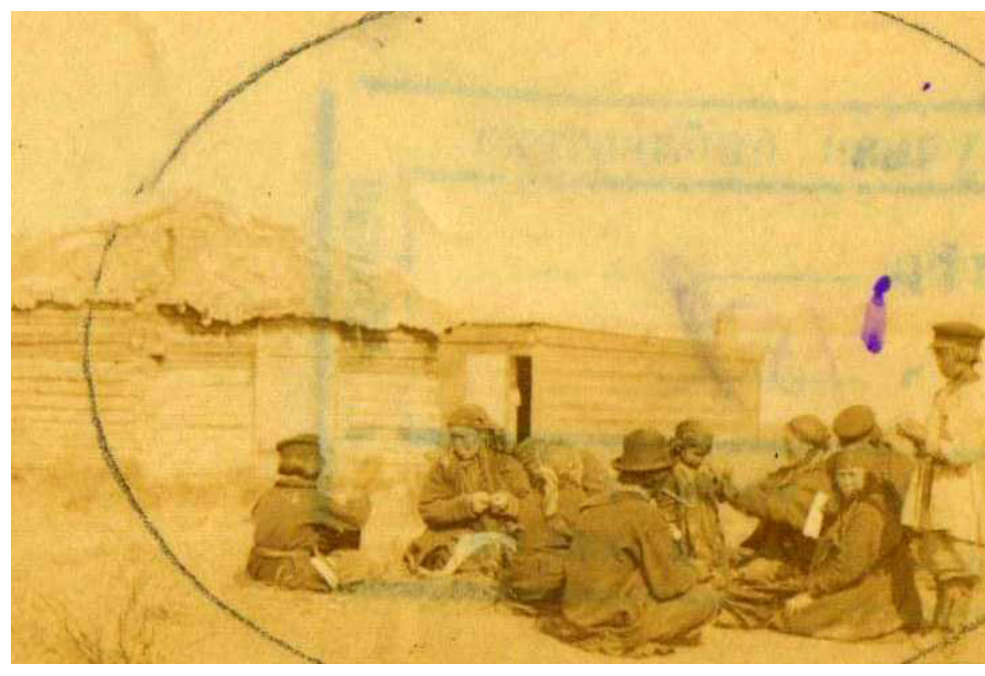

Фото 4. Айранная избушка. «Летом у юрты». Начало ХХ в. (Архив А. А. Ярилова // Рук. Фонд ХакНИИЯЛИ. Ф. 703. Фотокарточки).

Photo 4. An ayran house. «Summer near a yurt». Early 20th century (The library of A. A. Yarilov // Manuscript fund of KRILLH - F.703, photographs).

Юрты-поварни представляют собой небольшие постройки. Каждая постройка имеет печь, которая преимущественно служит для приготовления айрана ${ }^{1}$. В ней находится прибор для перегонки молочной водки, деревянная посуда для молока, кадки с айраном. А. А. Кузнецова отмечает также, что прежде таких построек не было (Кузнецова, 1898: 142). «Айранная избушка» могла иметь вид привычного для русской культуры деревянного сарая с крышей. У хакасов эта пристройка могла располагаться непосредственно вблизи с юртой (фото 4).

Амбары делали приподнятые на столбах (1-2 аршина), данная конструкция известна на Севере России у русских, когда амбары строили прямо в поле. Вероятно, эта строительная традиция была принесена вместе с русскими переселенцами в Сибирь, но местонахождение амбаров определялось уже двором. Русское старо-

${ }^{1}$ Для XIX в. отмечено широкое распространение айрана (Бутанаев, 2002: 12), напитка, приготовленного из кислого коровьего молока. 
жильческое население края, особенно его состоятельная часть, имела амбары двухэтажной конструкции.

Основными особенностями хозяйственных и жилых комплексов у русских старожилов края являются основательность построек, опрятность жилищ и крепость хозяйств (Шнейдер, 1928: 13). Заимствование амбаров хакасами произошло из русской строительной культуры. Прежде их функцию у бельтыр в последней четверти XIX в. выполняли ямы (oоpe $)^{1}$, расположенные прямо в поле. Их устройство было простым: копали яму, дно выстилали берестой, сверху закладывали яму жердями и засыпали землёй. Позднее появились деревянные лари или закрома (сакром, едыс) для хранения зерна в поле. Далее появляются крытые корой амбары на столбах высотой 1-2 аршина. Амбары середины XX в. имели конструкцию амбаров конца XIX-XX вв. (Шибаева, Хакасское жилище ... : 52). Амбары рубили из соснового леса. Крыша представляла собой устройство, состоящее из коры бересты, на которую сверху клали драньё Амбары имели двери на петлях (Кузнецова, 1898: 143). Об основательности конструкции амбаров свидетельствует тот факт, что средняя продолжительность их службы была соизмерима со службой избы и равнялась 70 годам (Кузнецова, 1898: 144).

Ю. А. Шибаева описывает конструкцию амбара, срубленного в начале XX в. С. И. Сыргашевым. Амбар был поставлен отдельно от дома с левой стороны в глубине двора. Он был срублен из сосновых бревен «в угол» и имел 13 венцов. Нижний ряд бревен находился на двух толстых балках, лежащих на земле. Амбар имел размеры 4,3×4 м. Спереди амбар был удлинен галерейками перед его дверьми, в результате чего крыша на полметра выступала вперед. Вверху крыша упиралась в выступающие вперед концы трех верхних венцов сруба. Галерейка имела пол в виде двух толстых досок, выступающих за сруб. Дверь в амбаре одностворчатая,

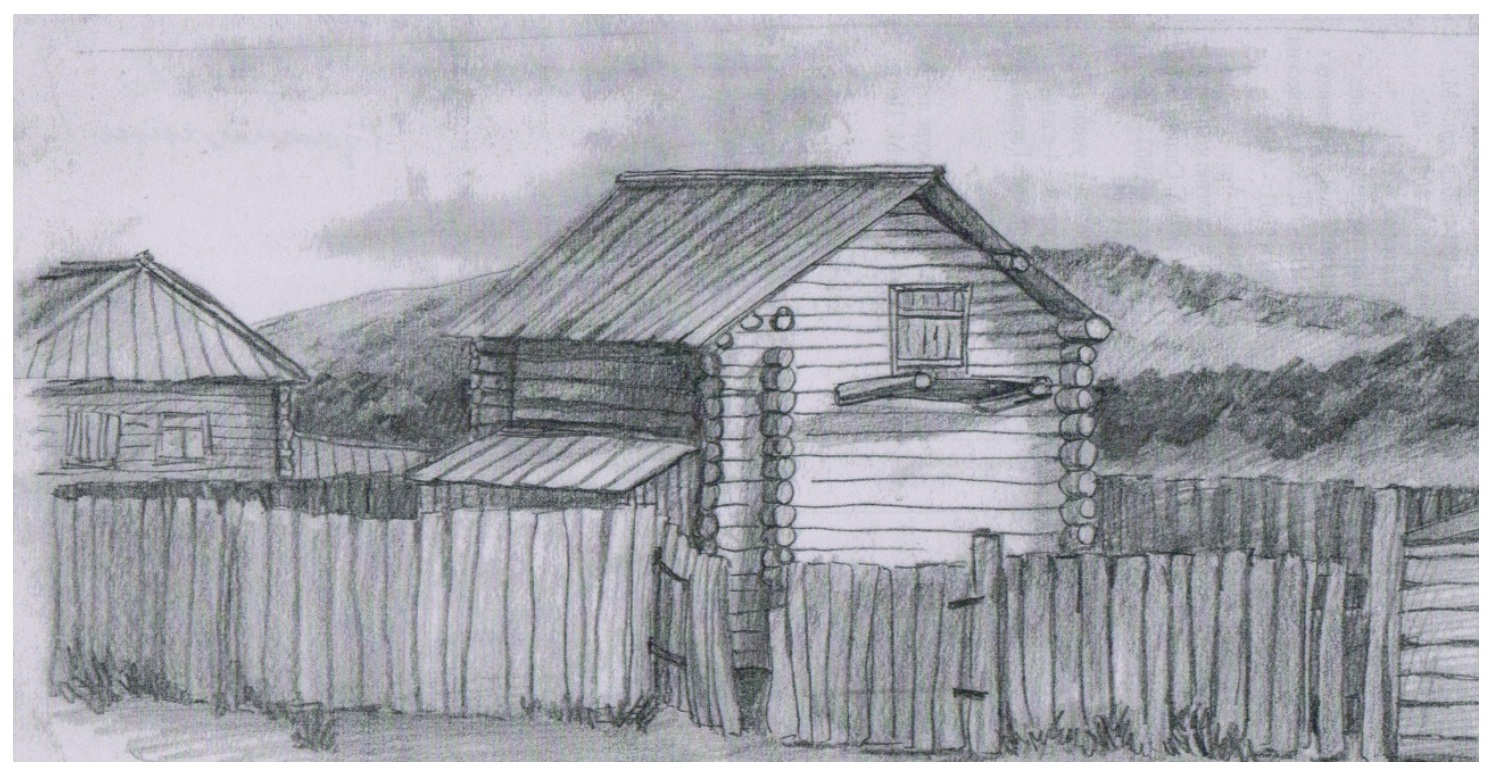

Рис. 1. Амбар Сафронова. Аал Сафронов, 1984 г. Рисунок художника Н. В. Учкиной из личного архива А. И. Поселянина.

Picture 1. Safronov's barn. Safronov's aal, 1984. A drawing by N.V. Uchkina, from the private library of A. I. Poselyanin.

\footnotetext{
${ }^{1}$ Ю. А. Шибаева упоминает конструкцию крыши у амбара, срубленного в начале ХХ в. С. И. Сыргашевым, покрытую корой лиственницы (Шибаева, Хакасское жилище ... : 53).

${ }^{2}$ Авторы выражают признательность археологу А. И. Поселянину за предоставленную возможность использования в работе рисунков архитектора Т. С. Добровой, художника Н. В. Учкиной (материалы этнографической экспедиции 1984 г. Хакасского областного краеведческого музея. Руководители: Э. А. Севостьянова, А. И. Поселянин; участники: В. Ф. Капелько, А. И. Готлиб, В. Чебочаков). Материалы хранятся в личном архиве А. И. Поселянина.
} 
поднятая над полом. Амбар имел тесовую крышу «на самцах» с желобами. Внутри амбар не имел потолка, вверху на срубе была укреплена балка, врубленная концами в стены. Пол амбара был выше, чем у галерейки. Внутри были досками огорожены закрома («сакром»). В амбаре хранилось, кроме зерна, ещё и хозяйственная утварь, одежда, охотничье снаряжение. Байские амбары строились иногда в два этажа (Шибаева Хакасское жилище ... : 52-53). Конструкции амбаров из числа хозяйственных построек у хакасов были заимствованы у русского населения региона, а особенностью амбаров были их вариации. Например, двухэтажные амбары бытовали только у хакасских баев (рис 1).

Небольшие амбары хакасов представляют собой конструкцию от 4-6 аршин ${ }^{1}$ длины, 4 и более аршин ширины и 6 аршин высоты. Прежде они делались из коры лиственницы (Кузнецова, 1898: 142) (рис. 2).

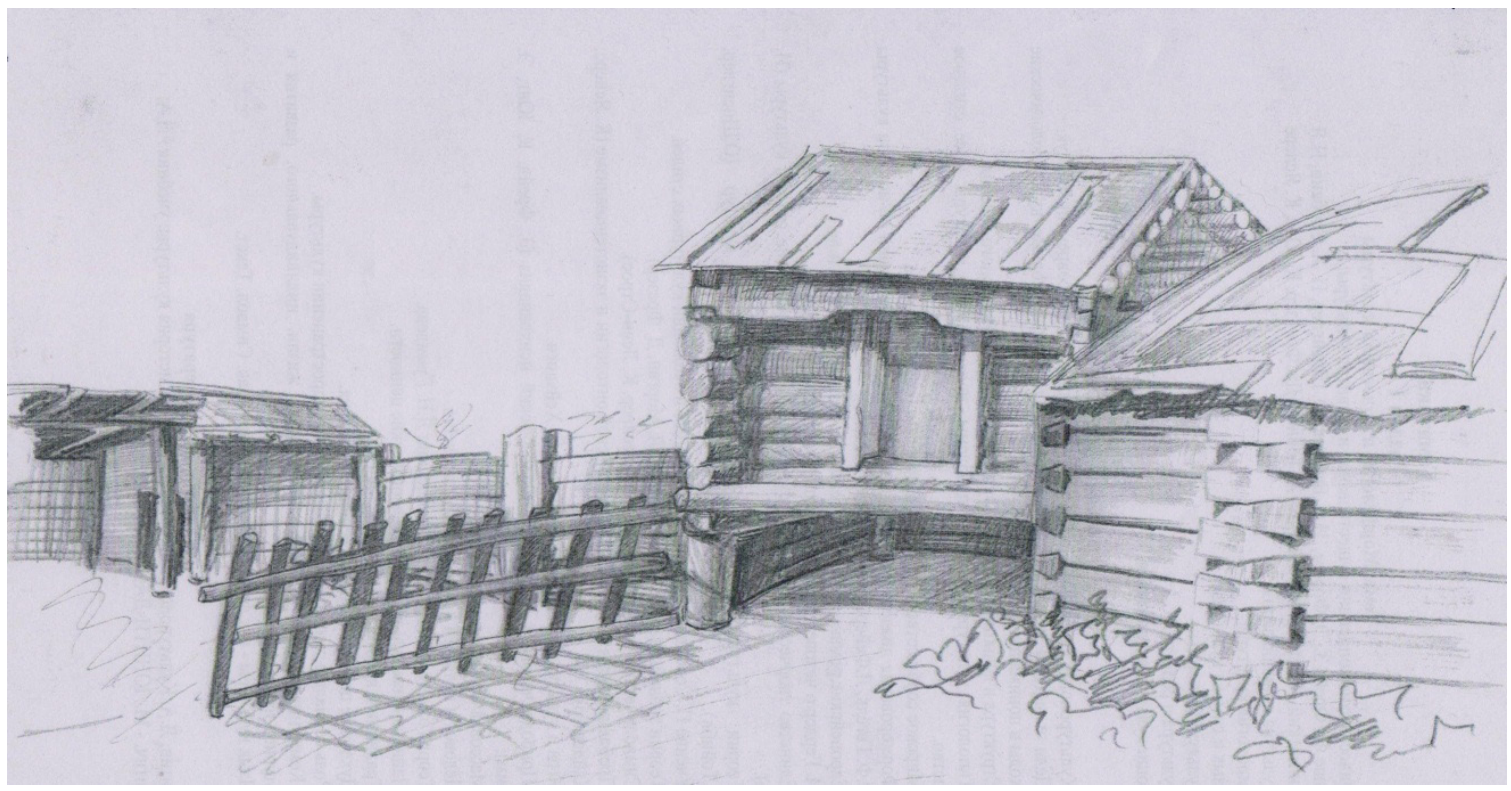

Рис. 2. Небольшой амбар, 1984 г. Рисунок художника Н. В. Учкиной из личного архива А. И. Поселянина. Picture 2. A small barn, 1984. A drawing by N.V. Uchkina, from the private library of A. I. Poselyanin.

Сарай представлял собой квадратную крышу из досок на четырех столбах на высоте двух и более сажень. Сарай функционально служил для сушки хлеба и особых, приготовляемых из молока сырцов (Кузнецова, 1898: 143).

Особое место в структуре усадьбы хакасов занимали постройки - навесы ${ }^{2}$ и зимние дворы $(\text { чабых каза) })^{3}$ для скота, которые были крыты соломой, сеном, хворостом, тесом с желобниками (водостоками). Некрытые летние пригоны и дворы представляли собой как общие, так и отдельные сооружения. Под влиянием русских сенокошение входит в жизнь хакасов. Ранее хакасы вырывали траву руками или срезали с помощью серповидного ножа (орғах). Эту траву в виде снопиков развешивали для просушки. Полностью обеспечить скот травой не удавалось, поэтому кормили ей молодых или обессиленных животных (Патачаков, 1956: 51).

\footnotetext{
${ }^{1}$ Аршин - 0,7112 м.

2 Под навесами хранили телеги, сани, охотничьи и рыболовные снасти и прочий сельскохозяйственный инвентарь (Патачаков, 1982: 34).

${ }_{3}^{3}$ Ю. А. Шибаева отмечает, что все загоны, сараи, навесы имели общий термин «хаза». Вариации сараев и загонов, известных под этим термином появились уже позднее, позднее же поменялось их функциональное назначение. Например, «хаза» с крышей имел номинацию «чаабых хаза». Вероятно, по мнению исследователя, ранее хаза был открытым и это есть свидетельство его архаичности (Шибаева, Хакасское жилище ... : 51).
} 
Под влиянием русских появляются новые орудия для заготовки сена, что в свою очередь способствует изменению содержания скота и развитию хозяйственных построек для этого. Места для хранения сена (сенники) были огорожены, также сено иногда набрасывали на крытый навес, что также выполняло роль сенника (Кузнецова, 1898: 143). Постройка скотных дворов была обусловлена изменениями в содержании крупного рогатого скота. На ночь скот загоняли в хлев, а корм давался при открытых пригонах. В теплые дни скот выпускали в поле на свободный выпас. Разведение свиней было заимствованно у русских. Их содержали в стайках, но и могли они гулять свободно, поэтому часто можно было видеть этих животных, вольготно разгуливающих по поселению, что не раз доводилось наблюдать автору этой статьи во время своих этнографических экспедиций по ХМК. Разведение домашней птицы (куры, утки, гуси), также требовало наличия стаюшек-курятников.

Как отмечает Ю. А. Шибаева, постройка отдельного хозяйства часто не имела огороды, так что двери юрты или дома выходили прямо на дорогу или степь (Шибаева, Хакасское жилище ... : 49). Скотные дворы же были огорожены. В качестве изгороди использовали жерди, в этом случае это был вариант русской поскотины - выгона или изгороди, прилегающих к деревне и огороженных, где скот пасся без пастуха (Словарь русских говоров южных районов Красноярского края, 1988: 301-302). Поскотина отгораживала территорию степных выгонов от покосов.

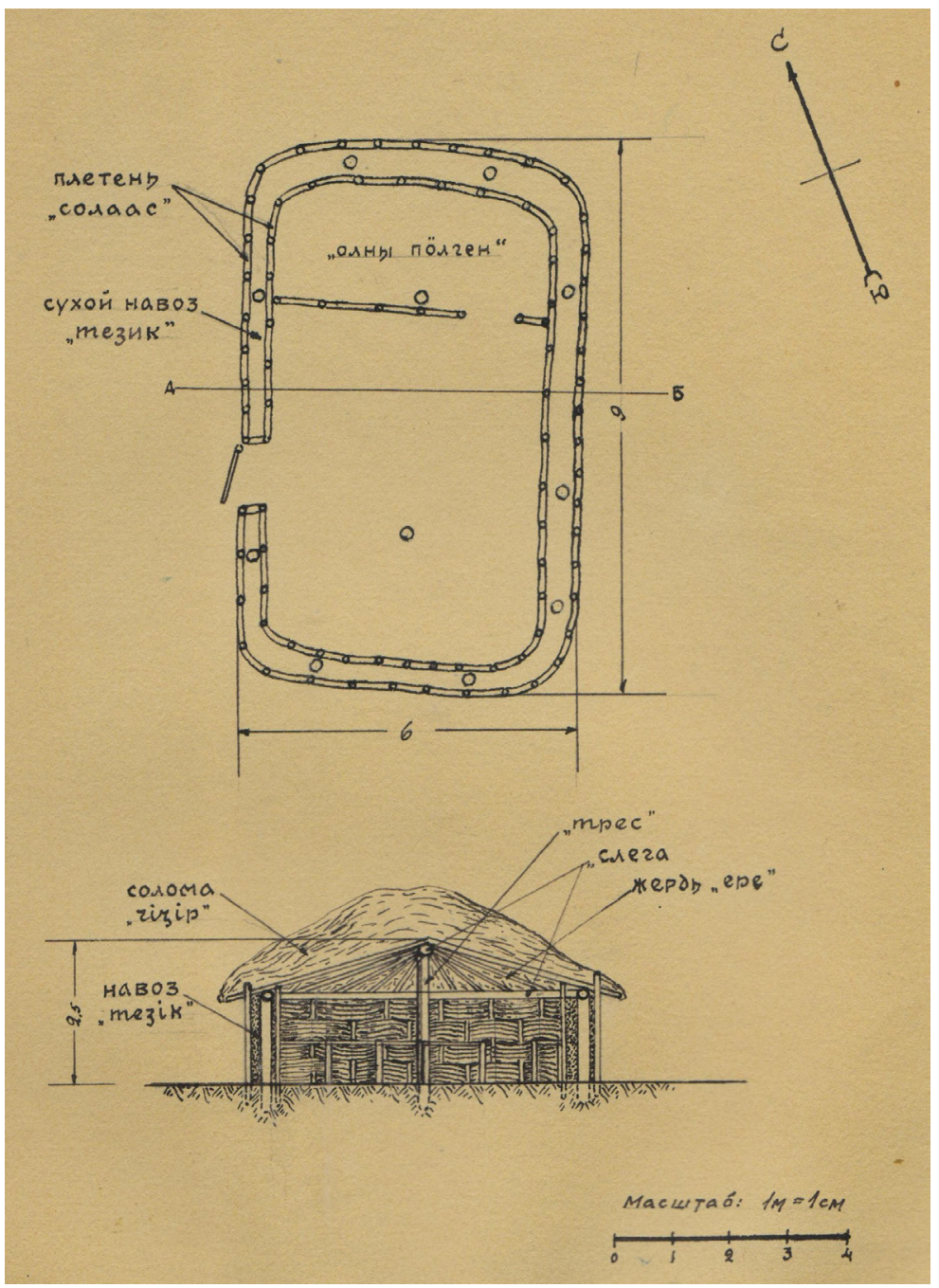

Рис. 3. Плетенный сарай для скота - солаас. Таштыпский район. 19.07.1947 2. (Шибаева, Чертежи по жилищу хакасов).

Picture 3. A wicker barn for cattle - solaas. Tashtypsky raion. July 19, 1947 (Source; Shibaeva, Khakass housing plans).
В этом случае она тянулась на несколько километров. Изгородью для скотных дворов служил плетень березовый, тополевый и даже тальниковый, в зависимости от местности. Дворы для овец чаще всего окружали тыном или частоколом (Кузнецова, 1898: 143). По мнению Ю. А. Шибаевой, плетеные изгороди из тальника и «сидень» (конструкция, когда в пазы врытых столбов горизонтально врубались плахи), которые использовались и при возведении крытых помещений для скота, являлись наиболее архаичными (Шибаева, Хакасское жилище ... : 51).

Бытовали сараи для скота (рuс. 3), по форме напоминающие юрту. Видимо их изготовление было привычнее для коренного населения, чем других построек, поэтому они были востребованы в хозяйстве хакасов. Для слабых овец существовали специальные полуземляные клетушки «сулан», где их подкармливали сеном (Бутанаев, 2002: 16).

Влияние русского населения в крае сказалось и на огораживании хакасами своих дворов. Если раньше юрты стояли в степной или притаежной долинной местности, то в течение XIX в. постепенно появляются огороженные дворы и усадьбы. 
В первую очередь ограды появились у хакасских баев. Причём, по мнению Ю. А. Шибаевой, появление огороженных усадеб и дворов под влиянием русской культуры подтверждается отсутствием специальной терминологии у хакасов. Двор, усадьба одинаково называются «сидень» (забор, ограда) (Шибаева, Хакасское жилище ... : 52).

Скотные дворы в зимних улусах хакасов, по свидетельству А. А. Кузнецовой, отличались большей чистотой, чем летние. Скотные дворы летних улусов не чистили и по мере их загрязнения все постройки просто переносили на другое место и перекочевывали (Кузнецова, 1898: 143-144).

Интересно, что огораживание возделываемых участков (огородов) в целом более позднее явление в ХМК. Представляется возможным связать его с влиянием уже переселенческой традиции, когда русские переселенцы, прибывшее в край после отмены крепостного права, привнесли эту особенность на бескрайние просторы Сибири. Если старожильческое русское население края возделывало участки земли и огораживания, как правило, не практиковало, то русские переселенцы, прибывшие из малоземельных районов юга Европейской России, привносили на новые места их расселения привычные для их родины методы и практики хозяйствования. В последующее время широкому ассортименту огородных культур, имевшему распространение у старожилов и коренных жителей края, способствовало именно введение в сельскохозяйственный оборот новых культур, привнесенных в край русскими переселенцами. Например, картофель, разводимый старожилами в огородах, под влиянием переселенцев стали культивировать в полях. Они же научили старожилов бахчеводству (Списки населенных мест Российской империи, 1864: 38).

Радикальные изменения в сфере землепользования и успехи в сельском хозяйстве Приенисейского края, по подсчетам В. А. Смирнова, были как количественные (по критерию площадей, занятых под посев), так и качественные (удобрение, орошение, мелиорация земель, применение стального плуга и машин, введение в оборот новых растений) (Смирнов, 1928: 40). Таким образом, утрата прежнего неограниченного земельного простора и начало земельного утеснения в период массовых переселений в крае приводило к тому, что у населения края менялись прежние способы обработки земли и осуществлялся переход к новым.

Диалектное слово «огорода», «огородец», «огородина» имело широкое распространение в ХМК и означало как привычный и сейчас для нас термин «огород», так и загородку, маркирующую его границы (Словарь русских говоров южных районов Красноярского края, 1988: 236-237). Чалдоны ХМК упоминают о том, чтобы огороды (загородки) находились в исправном состоянии, постоянно требовался присмотр: заменить ли сгнившие или сломанные деревянные колья, жерди. Иногда в качестве вертикальных кольев использовали осину, в этом случае, если осиновые колья оказывались во влажной местности (например, в мочагах), они прорастали, превращаясь в дерево (информант А. П. Терских, полевые материалы Е. В. Прищепы, 2003 г.). Появление огороженных дворов у хакасов происходит сначала у баев, а затем встречается и распространяется повсеместно.

В системе усадебного комплекса коренного населения, особенно часто и плотно общающегося с русскими крестьянами, были баня и погреб (Патачаков, 1982: 35). Бани (мылча) являлись постройками, заимствованными у русского населения. Уже в середине XIX в. у русских старожилов ХМК стали преобладать бани «по белому», при параллельном широком распространении бань «по-черному», использовавшихся также в различных хозяйственных целях, например, для высушивания льна (АРГО, р. 57, оп. 1, № 2, л. 4; информант А. Г. Калачев, полевые материалы Е. В. Прищепы, 1995 г.). «Белые» бани имели дымоход и потому были светлыми, уютными и более гигиенически пригодными для мытья.

Старожильческая традиция мытья в бане повлияла и на коренное население ХMК (puc. 4). На 1910 г. в хакасских поселениях насчитывалось 335 бань (мылча) двух типов: хара мылча («черная» баня») и ах мылча («белая» баня») (Бутанаев, 1998: 92). Однако широкого распространения 


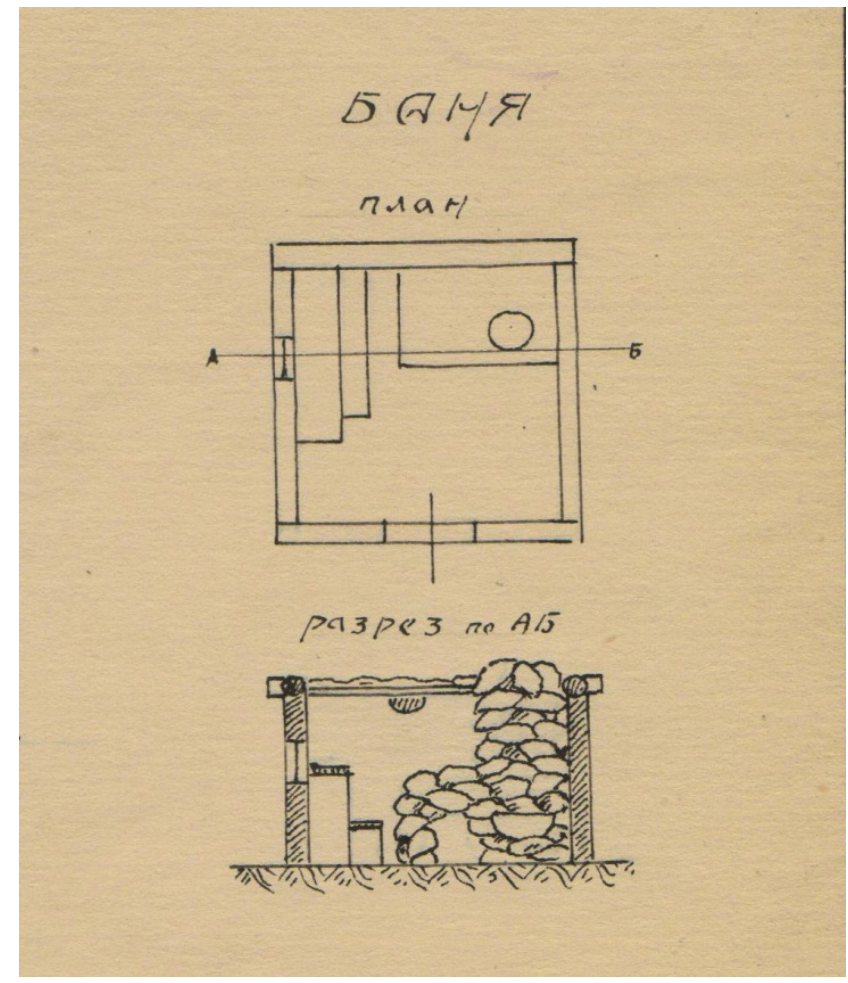

Рис. 4. Баня Егора Матвеевича Канзычакова, сеок хобый. Улус Н. Сира, Таштыпский район. 14.07.1948 г. (Шибаева, Чертежи по жилищу хакасов).

Picture 4. Bathhouse of Yegor Matveevich Kanzichakov, tribe hoby. Country S. Sira, Tashtypsky district. 14 july 1948 year

(Shibaeva, the drawings on the khakass housing). эти бани не получили, так как, согласно хакасским представлениям, от мытья в бане кожа становится хрупкой и не держит тепла тела, а потому мылись преимущественно в юрте.

Бани хакасы, как и русские, строили из строевого леса: лиственницы или сосны. Часто хакасы практиковали строительство бани из разобранных юрт (Шибаева Хакасское жилище: 89). Отличительной особенностью конструкции мылчи в XIX в. было отсутствие чердачной крыши (puc. 4). Деревянный потолок в такой бане засыпали землей или закладывали дерном. Сухой климат и низкое количество осадков ряда степных районов Хакасии позволял обходиться без крыши. В основном большее распространение бань было отмечено именно в земледельческих хозяйствах хакасов. В 124 хозяйствах на конец XIX в. всего было 19 бань, причем 16 из них - в земледельческих (Кузнецова, 1898: 144).

Свободный и не отличающийся правильностью планировки характер размещения селений и расположения жилищ и хозяйственных построек - характерная черта для традиционных хакасских улусов XIX в. (Прищепа, 2018: 86). Обрусевшие же улусы имели уличную планировку, где за жилищами избами и юртами были расположены дворы

с различными хозяйственными постройками, как в русских поселениях. Поселения хакасов, совместно проживающих с русскими, имели прямые улицы с промежутками, что соответствовало планировке русских старожильческих поселений. Жилища при этом «в связи с нежилыми не стоят, кроме двора, устраиваемого из заплотника в столбах и то не у многих». Избы выходят окнами на улицу и во дворы (Кузнецова, 1898: 144-145).

\section{Результаты взаимодействия материальных культур народов Хакасско-Минусинского края в XIX-XX вв.}

Таким образом, русская строительная культура оказала значительное влияние на развитие комплекса жилищно-хозяйственных построек хакасов и формирование облика их нового усадебно-жилищного комплекса в XIX-XX вв. Существенное влияние на формирование системы хозяйственного комплекса и на его развитие повлиял переход коренного населения региона с полукочевого на оседлый образ жизни, повлекший заимствование у русского населения строительных приемов возведения хозяйственных построек и их адаптацию к новым условиям образа жизни. Ранее кочевой образ жизни являлся фактором, который в основном обуславливал существование тех или иных традиционных вариантов построек, имевших исторические условия существования.

В целом процессы развития жилищно-усадебного комплекса хакасов на рубеже веков характеризовались трансформацией традиционных поселений, появлением смешанных форм усадебно-жилищных комплексов с активной нивелировкой этнически значимых черт и сохранением лишь отдельных традиционных элементов. Исторически развитие усадебно-жи- 
лищного комплекса шло по пути складывания единой усадьбы, в которой в пределах зимника и летника располагались разные типы жилых традиционных и заимствованных хозяйственных построек и жилищ. В этот период летник и зимник обретают черты и воспринимаются как единое целое одного жилищно-усадебного комплекса. Важным моментом в этом процессе становится образование постоянных хакасских поселений, часть из которых уже подобно крестьянским русским деревням обретает уличную планировку, а коренные жители уже находятся на постоянном местожительстве. Отмечено, что усадьбы баев имели больше черт русского типа и переход к усадьбам подобного типа произошел у них быстрее.

Главное сложившееся ядро построек у хакасов ко второй половине XIX - началу XX в. имело в своей основе традиции русского жилищного комплекса. Так, в течение XIX в. появляются огороженные дворы, сначала у баев, а затем и у остальных жителей. Более тесное знакомство с земледельческой культурой и потребность в хранении зерновых культур вызвали необходимость в строительстве амбаров, которые заменили ямы-ооре в поле. В результате амбары коренного населения конца XIX - начала XX в. строились уже как традиционные русского типа: рубленные из дерева, двухэтажные, с тесовой крышей. Так, итогом развития жилищно-усадебного комплекса у хакасов на рубеже веков стало складывание единой усадьбы, в которой в пределах зимника и летника располагались разные типы жилых традиционных и заимствованных хозяйственных построек.

Несомненным новым заимствованием из русской усадебно-жилищной культуры является постройка бани. Бани у старожильческого населения были индивидуальные, как правило, стоящие в отдалении от усадеб из соображений пожаробезопасности (Прищепа, 2018: 147). Бани, бытовавшие в крае, были двух типов: «черная» и «белая», в этих же конструктивных особенностях бани (мылча) были известны и у хакасов: хара мылча («черная») и ах мылча («белая»). Вхождение бани в строительный комплекс построек коренного населения, так же как и других построек, сначала произошло у владельцев зажиточных усадеб, чьи хозяйства имели земледельческую направленность, а далее распространились повсеместно. До середины XX в. в быту хакасов имели распространение бани «мылча», которые соответствовали типу русской бани «по-черному».

За двором обычно располагались огороды, а знакомство хакасов и культивирование большего, чем у русских старожилов ассортимента огородных культур, состоялось в результате культурных контактов с русскими переселенцами региона.

Видимо, достаточно архаичной традицией следует считать бытование построек общественного пользования: колодцев и печей, которые дополняли весь усадебный комплекс коренного населения. Дальнейшее пополнение населения ХМК новыми переселенцами из разных уголков Российской Империи вносило свои изменения в формирование и развитие усадебно-жилищного комплекса построек, который получил последующие изменения. Все они были обусловлены привнесением новых строительных приемов и их распространением в обустройстве как жилищ, так и хозяйственных построек. Постройки, которые в большей степени соответствовали природно-климатическим и экономическим характеристикам, получали наибольшее распространение и бытование в регионе и сохранялись вплоть до наших дней.

\section{Заключение}

Жилище для человека традиционной культуры являлось моделью мира и несло в себе его черты. В жилище народа отражено его мировоззрение, жилище является - одним из главных элементов системы жизнеобеспечения человека (Прищепа, 2018: 5). На протяжении XIX-XX вв. в ХMК мы наблюдаем стремительные процессы изменения структуры привычной традиционному образу жизни хакасов системы усадебно-жилищного комплекса, что оказалось обусловленным взаимодействием аборигенных и пришлых материальных культур, образом жизни, условиями и спецификой хозяйственной деятельности всего населения края. 
Несомненно, что XX в. оказался переломным моментом в вопросах обретения хакасами своего исторического имени (Тугужекова, 2017), процессами стремительной трансформации их материальной культуры и в целом образа жизни.

Аналогичные процессы происходили у другого тюркского этноса Саяно-Алтая - тувинцев. Особенности историко-политических факторов, территориальная изолированность Тувы, расположение ее в географическом центре Азии, среди высоких гор, явилось местом формирования «культур полукочевников и кочевников, как аридной зоны, так и холодного пояса Земли», являясь древним очагом «взаимодействия хозяйственно-культурных типов кочевых скотоводов степей и охотников-оленеводов тайги, сохранившимся до середины XX в.» (Вайнштейн, 1972: 8, 10). Изолированность территории (до середины XX в.), слабая интенсивность хозяйственных контактов (в основном меновая торговля с пограничными казаками, иностранными купцами) и небольшое количество пришлого населения обосновавшегося здесь (на примере этноконфессиональной историко-культурной группы - староверов), являлись определяющими факторами, которые способствовали более длительному сохранению самобытной культуры этноса, в сравнении с хакасами. Скотоводческий тип хозяйства тувинцев способствовал долгому сохранению традиционного типа жилища - войлочной юрты , удобство и универсальность которой для кочевой жизни неоспоримо, а кочевой характер культуры определял, так же как, у основной массы родоплеменных групп хакасов (например, у скотоводов-качинцев в XIX в.) скотоводческую направленность ограниченного количества хозяйственных построек. Если процессы перехода к оседлости у хакасов происходили интенсивно уже в конце XIX - начале XX в., что в свою очередь находит отражение в генезисе усадебножилищной культуры, то переход на оседлость тувинцев происходит только в середине XX в. Уход в прошлое кочевого быта тувинцев был во многом обусловлен аналогичными причинами и факторами, которые ранее коснулись хакасского этноса. Более высокая интенсивность процессов перехода хакасов к оседлости объясняется историко-политическими причинами (вхождение Хакасии в состав Российской Империи произошло в начале XVIII в.). Это историческое событие способствовало началу колонизационных процессов и повлекло изменения в культурных сферах жизни аборигенного общества. Поэтому процессы взаимокультурного влияния на генезис, рассматриваемых нами элементов материальной культуры, и в целом образа жизни хакасов, начали развиваться в русле общероссийских векторов развития ранее, нежели у тувинцев, у которых эти процессы имели более поздние временные рамки. В конечном итоге в XX в., для народов Саяно-Алтая, явилось распространение одинаковых принципов возведения жилища и его конструкций, планировки усадьбы, околожилищного пространства и поселений. Соприкосновение разных культурных традиций послужило началу процессов культурного взаимодействия, во многом унифицированного, но в котором важное место занимает развитие и эволюция основных элементов усадебно-жилищного комплекса коренного населения по русскому образцу. Этот период явился для коренного этноса новым этапом развития самоидентификации, что нашло свое отражение во всех культурных сферах. В материальной культуре изменения были связаны с научно-техническими достижениями прошлого века, процессами урбанизации и переходом номадов на оседлость.

\section{СПИСОК ЛИТЕРАТУРЫ}

Бутанаев, В. Я. (2002) Социально-экономическая история Хонгорая (Хакасии) в XIX - начале ХХ в. Абакан : Изд-во ХГУ им. Н. Ф. Катанова. 212 с.

Бутанаев, В. Я. (1998) Этническая культура хакасов. Абакан: Изд-во ХГУ им. Н. Ф. Катанова. 352 c.

Вайнштейн, С. И. (1972) Историческая этнография тувинцев: Проблемы кочевого хозяйства. М. : Наука. 314 с.

Вайнштейн, С. И. (1991) Мир кочевников Центра Азии. М.: Наука. 296 с. 
Георги, И. Г. (1799) Описание всех в Российском государстве обитающих народов, также их житейских обрядов, вер, обыкновений, жилищ, одежд и прочих достопамятностей: в 4 ч. СПб.: Имперская АН. Ч. II. О народах татарского племени и других нерешенного еще происхождения северных сибирских. 246 с.

Грумм-Гржимайло, Г. Е. (2014) Западная Монголия и Урянхайский край. Антропологический и этнографический очерк этих стран //Урянхай. Тыва дептер. Антология научной и просветительской мысли о древней тувинской земле и её насельниках, об Урянхае - Танну-Туве, урянхайцах - тувинцах, о древностях Тувы: в 7 т. (2014) / сост. С. К. Шойгу. Кызыл : ОАО «Тываполиграф». Т. 2. Племена Саяно-Алтая. Урянхайцы (VI в. - начало XX в.). 664 с. C. 496-638.

Енисейская губерния. Список населенных мест по сведениям 1859 г. (1864) СПб. : Типография Карла Вульфа. 74 с.

Катанов, Н. Ф. (1897) Отчёт о поездке, совершенной с 15 мая по 1 сентября 1896 года в Минусинский округ Енисейской губернии. Казань: Типо-литография Императорского Казанского университета. $104 \mathrm{c}$.

Кузнецова, А. А. (1898) Жилища, одежда и пища минусинских и ачинских инородцев. Красноярск : Типография Енисейского губернского управления. 213 с.

Клеменц, Д. (2015) Минусинская Швейцария и боги пустыни (Из дневника путешественника) // Ада чир-суу = Отечество: краеведческий альманах. Абакан. Вып. 3. 240 с. С. 205-226.

Лаппо, Д. Е. (2009) Общественное управление Минусинских инородцев // Обычное право и общественное управление минусинских «инородцев». Исследования разных лет (XIX - начало XXI в.) / сост. и авт. предисл. В. Ф. Буров. Абакан : Хакасское книжное издательство. 288 с. C. 73-166.

Мамышева, Е. П. (2018) Столыпинская переселенческая политика и создание волостных учреждений в Енисейской губернии (на материалах минусинских инородцев) // IV Центральноазиатские исторические чтения. Пространство культур: через призму единства и многообразия: сборник материалов Международной научно-практической конференции (г. Кызыл, 20-23 сентября 2018 г.) / отв. редактор 3. Ю. Доржу. Кызыл : Изд-во ТувГУ. 350 с. С. 231-233.

Мамышева, Е. П. (2008) Хакасия: от Степных дум к автономной области. Абакан : Изд-во Хакасского государственного университета им. Н. Ф. Катанова. 124 с.

Очерки истории Хакасии (с древнейших времен до современности) (2008) / гл. ред. В. Я. Бутанаев; науч. ред. В. И. Молодин. Абакан : Изд-во Хакасского государственного университета им. Н. Ф. Катанова. 672 с.

Патачаков, К. М. (1956) К вопросу о влиянии русской культуры на культуру и быт хакасов в XVIII-XIX вв. // Записки ХакНИИЯЛИ. Вып. IV. Абакан : Типография изд-ва «Советская Хакасия». С. 47-62.

Патачаков, К. М. (1982) Очерки материальной культуры хакасов. Абакан: Хакасское отделение Красноярского книжного изд-ва. 88 с.

Паллас, П. С. (1788) Путешествие по разным провинциям Российского государства: в 3 ч. СПб. : ИАН. Ч. III. 624 с.

Потапов, Л. П. (1957) Происхождение и формирование хакасской народности. Абакан: Хакасское книжное издательство. 308 с.

Прищепа, Е. В. (2018) Жилища населения Хакасско-Минусинского края в традиционной системе жизнеобеспечения XVIII-XX вв. (на примере хакасов и русских старожилов) / науч. ред. В. Н. Тугужекова. Абакан : Изд-во «Бригантина». 180 с.

Скобелев, С. Г. (2017) Енисейские кыргызы - кочевники или земледельцы: задачи преодоления распространенного стереотипа // Научное обозрение Саяно-Алтая. Археология. № 1 (17). С. $76-85$.

Словарь русских говоров южных районов Красноярского края (1988). 2-е изд., перераб. и доп. Красноярск : Изд-во Краснояр. ун-та. 448 с. 
Смирнов, В. А. (1928) Исторический очерк Приенисейского края. Ч. 2. Красноярск : Изд. Бюро краеведения при Средн.-Сиб. отд. РГО. 47 с.

Тугужекова, В.Н.(2017) 1917 год и хакасское национальное движение (к 100-летию первых съездов хакасского народа) // Материалы Всеросийской научно-практической конференции «Проблемы этногенеза хакасского народа», посвященной 100-летию первых съездов хакасского народа и возрождения народного имени (23-25 августа 2017 г.) / отв. ред. В. Н. Тугужекова. Абакан : ХКИ. 80 с. С. 23-37.

Тугужекова, В. Н. (2018) Роль Н. Ф. Катанова в изучении истории и культуры народов Центральной Азии // IV Центральноазиатские исторические чтения. Пространство культур: через призму единства и многообразия: сборник материалов Международной научной-практической конференции (г. Кызыл, 20-23 сентября 2018 г.) / отв. редактор 3. Ю. Доржу. Кызыл : Издво ТувГУ. 350 с. С. 257-260.

Хакасско-русский словарь = Хакас-орыс сӧстік : (ок. 22 тыс. слов) (2006) / под общ. ред. О. В. Субраковой. Новосибирск : Наука. 1111 с.

Шнейдер, А. Р. (1928) Население Приенисейского края. Красноярск : Бюро краеведения при Средне-Сибирском отделе РГО. 22 с.

Дата поступления: 04.06.2018 г.

\section{REFERENCES}

Butanaev, V. Ia. (2002) Sotsial'no-ekonomicheskaia istoriia Khongoraia (Khakasii) v XIX - nachale $X X v v$. [A socio-economic history of Khongorai (Republic of Khakassia) in 19th - early 20th centuries]. Abakan, Izd-vo KhGU im. N. F. Katanova. 212 p. (In Russ.).

Butanaev, V. Ia. (1998) Etnicheskaia kul'tura khakasov. [Khakass ethnic culture]. Abakan, Izd-vo KhGU im. N. F. Katanova. 352 p. (In Russ.).

Vainshtein, S. I. (1972) Istoricheskaia etnografiia tuvintsev: Problemy kochevogo khoziaistva [Historical Ethnography of Tuvans: problems of nomadic economy]. Moscow, Nauka. 314 p. (In Russ.).

Vainshtein, S. I. (1991) Mir kochevnikov Tsentra Azii [The world of nomads in the center of Asia]. Moskow, Nauka. 296 p. (In Russ.).

Georgi, J. G. (1799) Opisanie vsekh v Rossiiskom gosudarstve obitaiushchikh narodov, takzhe ikh zhiteiskikh obriadov, ver, obyknovenii, zhilishch, odezhd i prochikh dostopamiatnostei: [A description of peoples inhabiting the state of Russia, as well as their everyday rites, faiths, customs, dwellings, clothes and other attractions] : in 4 vols. St. Petersburg, Imperskaia AN. Ch. II. O narodakh tatarskogo plemeni i drugikh nereshennogo eshche proiskhozhdeniia severnykh sibirskikh [On the of the Tatar tribe and others of origin yet unknown in the north of Siberia]. 246 p. (In Russ.).

Grumm-Grzhimailo, G. E. (2014) Zapadnaya Mongoliya i Uryanhajskii krai. Antropologicheskii i etnograficheskii ocherk etikh stran [Western Mongolia and Uriankhai krai: An anthropological and ethnographic sketch of these countries] In: Uriankhai. Tyva depter. Antologiia nauchnoi i prosvetitel'skoi mysli o drevnei tuvinskoizemle i ee nasel'nikakh, ob Uriankhae-Tannu-Tuve, uriankhaitsakh-tuvintsakh, o drevnostiakh Tuvy [Uryankhay. Tyva depter. Anthology of scientific and educational thought of ancient Tuvan land and its inhabitants, the Uryankhay - Tannu-Tuva, the uriyangkhai - Tuva, on the antiquities of Tuva] : in 7 vol. / sost. S. K. Shoigu. Kyzyl, OAO «Tyvapoligraf». Vol. 2. Plemena Saiano-Altaia. Uriankhaitsy (VI v. - nachalo XX v.). 664 p. Pp. 496-638. (In Russ.).

Eniseiskaia guberniia. Spisok naselennykh mest po svedeniiam $1859 \mathrm{~g}$. [The Yenisei province: A list of locations inhabited as of 1859.] (1864). St. Petersburg, Tipografiia Karla Vul'fa. 74 p. (In Russ.).

Katanov, N. F. (1897) Otchet o poezdke sovershennoi s 15 maia po 1 sentiabria 1896 goda $v$ Minusinskii okrug Eniseiskoi gubernii [Report on the trip made from May 15 to September 1, 1896 to Minusinsk okrug of the Yenisei province]. Kazan', Tipo-litografiia Imperatorskogo Kazanskogo universiteta. 104 p. (In Russ.). 
Kuznetsova, A. A. (1898) Zhilishcha, odezhda i pishcha minusinskikh $i$ achinskikh inorodtsev [Dwellings, clothes and food of Minusinsk and Achinsk non-Russian inhabitants]. Krasnoiarsk, Tipografiia Eniseiskogo gubernskogo upravleniia. 213 p. (In Russ.).

Klements, D. (2015) Minusinskaia Shveitsariia i bogi pustyni (Iz dnevnika puteshestvennika) [The Minusinsk Switzerland and the gods of the desert (from a traveler's diary)]. Ada chir-suu = Otechestvo: kraevedcheskii al'manakh. Abakan. Issue 3. 240 p. Pp. 205-226. (In Russ.).

Lappo, D. E. (2009) Obshchestvennoe upravlenie Minusinskikh inorodtsev [Public administration of Minusinsk non-Russians]. In: Obychnoe pravo i obshchestvennoe upravlenie minusinskikh «inorodtsev»Issledovaniia raznykh let (XIX - nachalo XXI v.) [Customary law and public administration of Minusinsknon-Russians. Studies made from the 19th to early 21st century]/ ed. by V. F. Burov. Abakan, Khakasskoe knizhnoe izdatel'stvo. 288 p. Pp. 73-166. (In Russ.).

Mamysheva, E. P. (2018) Stolypinskaia pereselencheskaia politika i sozdanie volostnykh uchrezhdenii vEniseiskoi gubernii (na materialakh minusinskikh inorodtsev) [Stolypin's resettlement policy and the creation of volost' institutions in the Yenisei province: the case of Minusinsk nonRussians]. In: IV Tsentral' noaziatskie istoricheskie chteniia. Prostranstvo kul'tur: cherez prizmu edinstva i mnogoobraziia [4th Central Asian historical readings. Space of cultures: through the prism of unity and diversity] : proceedings of an international research conference (Kyzyl, 20-23 September 2018)] / ed. by Z. Yu. Dorzhu. Kyzyl, TuvGU Publ. 350 p. Pp. 231-233. (In Russ.).

Mamysheva, E. P. (2008) Khakasiia: ot Stepnykh dum k avtonomnoi oblasti [Khakassia: from the Steppe Dumas to an autonomous oblast]. Abakan, Izd-vo Khakasskogo gosudarstvennogo universiteta im. N. F. Katanova. 124 p. (In Russ.).

Ocherki istorii Khakasii (s drevneishikh vremen do sovremennosti) [Essays on the history of Khakassia: from ancient times to the present] (2008) / ed. by V. Ia. Butanaev. Abakan, Izd-vo Khakasskogo gosudarstvennogo universiteta im. N. F. Katanova. 672 p. (In Russ.).

Patachakov, K. M. (1956) K voprosu o vliianii russkoi kul'tury na kul'turu i byt khakasov v XVIII-XIX vv. [On the influence of Russian culture on the culture and life of the Khakass people in the 18th - 19th centuries.]. Zapiski KhakNIIIaLI, issue IV. Abakan, Tipografiia izd-va «Sovetskaia Khakasiia». 108 p. Pp. 47-62. (In Russ.).

Patachakov, K. M. (1982) Ocherki material'noi kul'tury khakasov [Essays on material culture of the Khakass people]. Abakan, Khakasskoe otdelenie Krasnoiarskogo knizhnogo izd-va. 88 p. (In Russ.).

Pallas, P. S. (1788) Puteshestvie po raznym provintsiiam Rossiiskogo gosudarstva [A journey to various provinces of the Russian state] : in 3 parts. St. Petersburg, IAN. Part III. 624 p. (In Russ.).

Potapov, L. P. (1957) Proiskhozhdenie i formirovanie khakasskoi narodnosti [The origin and formation of the Khakass nation]. Abakan, Khakasskoe knizhnoe izdatel'stvo. 308 p. (In Russ.).

Prishchepa, E.V. (2018) Zhilishcha naseleniia Khakassko-Minusinskogo kraia v traditsionnoi sisteme zhizneobespecheniia XVIII-XX vv. (na primere khakasov i russkikh starozhilov) [Habitations of the population of Khakass-Minusinsk region in the traditional lifestyle of the 18th - 19th centuries: the cases of the Khakass and Russian 'old-timers'] / ed. by V. N. Tuguzhekova. Abakan, Brigantina Publ. 180 p. (In Russ.).

Skobelev, S. G. (2017) Eniseiskie kyrgyzy - kochevniki ili zemledel'tsy: zadachi preodoleniia rasprostranennogo stereotipa [The Yenisei Kyrgyz - nomads or farmers? Challenging widespread stereotypes]. Nauchnoe obozrenie Saiano-Altaia. Arkheologiia, no. 1 (17), pp. 76-85. (In Russ.).

Slovar' russkikh govorov iuzhnykh raionov Krasnoiarskogo kraia [A dictionary of Russian dialects of southern regions of Krasnoyarsk krai] (1988). 2nd ed. Krasnoiarsk, Izd-vo Krasnoiar. un-ta. 448 p. (In Russ.).

Smirnov, V. A. (1928) Istoricheskii ocherk Prieniseiskogo kraia [A historical sketch of the Yenisei region]. Vol. 2. Krasnoiarsk, Izd. Biuro kraevedeniia pri Sredn.-Sib. otd. RGO. 47 p. (In Russ.). 
Tuguzhekova, V. N. (2017) 1917 god i khakasskoe natsional'noe dvizhenie (k 100-letiiu pervykh s'ezdov khakasskogo naroda) [1917 and the Khakass national movement (to the 100th anniversary of the first congresses of the Khakass people)]. In: Materialy Vserosiiskoi nauchno-prakticheskoi konferentsii «Problemy etnogeneza khakasskogo naroda», posviashchennoi 100-letiiu pervykh s"ezdov khakasskogo naroda i vozrozhdeniia narodnogo imeni (23-25 avgusta 2017 g.) [Proceedings of the allRussian research conference "Problems of ethnogenesis of the Khakass people", dedicated to the 100th anniversary of the first congresses of the Khakass people and the revival of the ethnonym (23-25 August 2017)] / ed. by V. N. Tuguzhekova. Abakan, KhKI. 80 p. Pp. 23-37. (In Russ.).

Tuguzhekova, V. N. (2018) Rol' N. F. Katanova v izuchenii istorii i kul'tury narodov Tsentral'noi Azii [N. F. Katanov's role in the study of the history and culture of the peoples of Central Asia]. In: IV Tsentral'noaziatskie istoricheskie chteniia. Prostranstvo kul'tur: cherez prizmu edinstva $i$ mnogoobraziia [4th Central Asian historical readings. Space of cultures: through the prism of unity and diversity] : proceedings of the International research conference (Kyzyl, 20-23 September 2018) / ed. by Z. Yu. Dorzhu. Kyzyl, Izd-vo TuvGU. 350 p. Pp. 257-260. (In Russ.).

Khakassko-russkii slovar' [AKhakass-Russian dictionary](2006)/ed.by O.V.Subrakova. Novosibirsk, Nauka. 1111 p. (In Russ.).

Shneider,A. R. (1928) Naselenie Prieniseiskogo kraia [The population of the Yenisei krai]. Krasnoiarsk, Biuro kraevedeniia pri Sredne-Sibirskom otdele RGO. 22 p. (In Russ.).

Submission date: 04.06.2018. 